\title{
Is Chain Affiliation a Strategic Asset or Constraint in Emerging Economies? Competitive Strategies and Performance in the Russian Hotel Industry
}

\author{
Päivi Karhunen ${ }^{1}(1) \cdot$ Svetlana Ledyaeva ${ }^{2} \oplus$
}

Received: 10 July 2020 / Revised: 3 February 2021 / Accepted: 22 April 2021 /

Published online: 7 June 2021

(C) The Author(s) 2021

\begin{abstract}
The purpose of the paper is to find out how chain affiliation, an important strategic choice and a key determinant for hotel performance, influences the strategy-performance nexus in the emerging economy context. It combines the resource- and institution-based views to investigate how chain affiliation moderates the relationship between competitive strategy and performance. This is done by distinguishing between market-based strategies based on differentiation or cost leadership, and non-market strategies that manifest in institutional advantage. The empirical analysis draws from original survey data on 162 hotels located in the Russian cities Moscow and St. Petersburg. The paper finds that first, in emerging economies the competitive edge of chain-affiliated hotels largely arises from market-based advantage, but only in terms of cost advantage. The finding that differentiation advantage is not an important factor of performance for chain-affiliated hotels suggests that firmlevel resources derived from chain affiliation would not transform into competitive advantage in the emerging economy context. Second, it is found that institutional advantage is more important determinant of performance for independent hotels, demonstrating the importance of local knowledge and relationships for firms in emerging economies. This finding also suggests that chain affiliation might be rather a strategic constraint than asset for creating superior performance via institutional advantages in the emerging economy context.
\end{abstract}

Keywords Chain affiliation · Competitive strategies $\cdot$ Firm performance $\cdot$ Hotel industry $\cdot$ Emerging economies $\cdot$ Russia

Päivi Karhunen

paivi.karhunen@aalto.fi

Extended author information available on the last page of the article 


\section{Introduction}

"What determines firm strategy and performance" is a fundamental question in strategic management and international business alike (Peng 2004). To answer this question, existing literature has often focused on the characteristics of the firm, in particular its resources and capabilities (Barney 1991; Barney et al. 2011). This resource-based view (RBV) initially maintains that the firm competes in the market either by offering differentiated products, or by attaining low cost position relative to its rivals (Conner 1991), and that the competitive advantage it gets is dependent on firm resources and its ability to deploy them efficiently.

The RBV was introduced as a firm-centered approach, implicitly assuming that the firm operates in an environment where market-supporting institutions are in place. This is understandable, taken that where institutions are strong in developed economies, their role maybe almost invisible (Meyer et al. 2009). In contrast, when markets malfunction, as in some emerging economies, the importance of institutions for firm strategies becomes evident (Ingram and Silverman 2002). Consequently, the RBV has been extended since its introduction to take into account the contextuality of resources. Researchers have argued that firm resources developed to fit certain institutional environment, would not be as applicable in a different institutional framework (Brouthers et al. 2008). Hence, resources and capabilities of firms from developed economies, where institutions are capable of supporting marketbased business activities, would not be effectively applicable in emerging economies with institutional voids (Khanna and Palepu 2000). Consequently, a direct transfer of strategies and business models from developed to emerging markets is often not possible. This is due not only to institutional voids, but also due to market characteristics such as consumer preferences and market behavior (Khanna and Palepu 2010; London and Hart 2004).

The notion of contextuality of resources has inspired an alternative approach to firm strategy: The institution-based view that suggests that competitive advantage can arise also from non-market resources (Peng et al. 2005), referred to as institutional advantage. Li and Zhou (2010) conceptualize such advantage as consisting of both tangible benefits such as access to government-controlled resources, and intangible benefits such as political support and goodwill. Such resources can be accessed through pursuing a non-market strategy by, for example, establishing close ties with political decision-makers (Guo et al. 2014; Li and Zhang 2007; Peng and Luo 2000).

The importance of institutions as determinant of firm strategy and performance is particularly great in emerging economies (Wright et al. 2005), and there is a mounting body of empirical research on non-market strategies and firm performance in these economies, predominantly China (Fan et al. 2013). Most studies explicitly focus on non-market strategies, whereas others link non-market and market-based components of firm strategy (Li and Zhou 2010). Existing research has mainly focused on firm characteristics such as size, ownership or age, or industry influence in terms of service versus manufacturing firms as moderators of the strategy-performance nexus (Fan et al. 2013). Studies that would investigate the implications of institutions and resources on firm performance in emerging economies at industry 
level have started to emerge only recently (Jiang et al. 2018; Tang et al. 2019). Yet, strategy and performance are very much industry-specific constructs, as the RBV inherently looks at the firm resources and their effect on strategies and performance relative to other firms in the same industry (Acquaah and Chi 2007; Mauri and Michaels 1998). This paper contributes to the debate on firm strategy as determinant of firm performance in emerging economies by providing an industry-level analysis.

In this paper we empirically analyze how chain affiliation, an important strategic choice and one of the key industry-specific determinants for hotel performance (Menicucci 2018), influences the strategy-performance nexus in the Russian emerging hospitality industry. We build on Ingram and Baum's (1997) argument that chain affiliation may be a strategic asset for hotels as it provides operating knowledge and economies of scale, but also a strategic constraint as fitting into the global strategy designed for the chain reduces the degrees of freedom that managers of individual hotels have to respond to their local environments. We combine resource- and institution-based views on firm strategy to make a distinction between market-based strategies, eventually leading to differentiation advantage or cost leadership as suggested by the RBV (Barney 1991), and non-market strategies that manifest in institutional advantage (Li and Zhou 2010). We suggest that chain affiliation would be an asset for hotels pursuing market-based strategies, but constrain the implementation of non-market strategies.

Our empirical analysis draws from the survey data on 162 Russian hotels located in the cities of Moscow and St. Petersburg and their suburbs. Our results suggest that first, in Russia, the competitive edge of chain-affiliated hotels largely arises from market-based advantage, but only in terms of cost advantage. Our finding that differentiation advantage is not an important factor of performance for chain-affiliated hotels indicates that firm-level resources derived from chain affiliation are not necessarily transferable into competitive advantage in the emerging economy context. Finally, we found that institutional advantage is more important determinant of performance for independent hotels, which demonstrates the importance of local knowledge and relationships for firms in emerging economies.

The article is structured as follows. We first present the theoretical framing of our study and construct our hypotheses. Then we describe our empirical methodology, including the data and methods of analysis, after which we present the results of the empirical analysis. We finish the paper with discussion of the results, including the limitations of our study and suggestions for future research.

\section{Theory and Hypotheses}

The theoretical framing of our study builds on two core concepts of strategic management: competitive advantage and performance. Strategic management theories have traditionally treated competitive advantage and superior performance as interchangeable constructs (Ma 2000), but there have been repeated attempts to detangle them conceptually (e.g., Ma 2000; Newbert 2008). In this paper, we treat competitive advantage and performance as two different constructs, and investigate their 
mutual relationship moderated by firm strategic choice, i.e., the hotel's decision to affiliate to a chain.

We investigate competitive advantage and its relationship to performance by integrating the RBV that builds on market-based sources of competitive advantage, and the institutional approach on business strategy that view non-market resources as sources for competitive advantage.

The RBV (Barney 1991) looks to the internal resources of the firm for the explanation of its performance relative to other firms in the same industry (Acquaah and Chi 2007). Hence, to gain an advantage over its competitors, the firm needs to possess firm-specific resources superior to its competitors, and be able deploy them efficiently. According to Barney (1991, p. 101), firm resources include "all assets, capabilities, organizational processes, information and knowledge, etc. controlled by a firm that enable the firm to implement strategies." These resources may be either tangible or intangible, or a combination of both. The understanding of the RBV on firm competitive advantage as based on a unique value creating strategy (Barney 1991, p. 102) echoes Michael Porter's (1980) classic definition of competitive advantage as resulting from the firm's ability to create for its buyers value that exceeds the firm' cost of creating it (Porter 1985). The two generic strategies to create superior value are to offer lower prices than competitors for equivalent benefits, or to provide unique benefits that more than offset a higher price, leading to competitive advantage in terms of cost leadership or differentiation, respectively (Porter 1985). In this paper we conceptualize these two forms of competitive advantage through the lens of the RBV, viewing them as resulting from the ownership and deployment of firm resources to implement either low-cost or differentiation strategy.

The RBV—or theory (Barney et al. 2011) — has been extended since its introduction to take into account the contextuality of resources. Researchers have argued that firm resources developed to fit certain institutional environment, would not be as applicable in a different institutional environment (Brouthers et al. 2008). Hence, resources and capabilities of firms from developed economies, where institutions are capable of supporting market-based business activities, would not be effectively applicable in emerging economies with institutional voids (Khanna and Palepu 2000).

The notion of contextuality of resources links to the institution-based view on business strategy that suggests that competitive advantage can also arise from nonmarket resources (Peng et al. 2005), referred to as institutional advantage. Li and Zhou (2010) conceptualize such advantage as consisting of both tangible benefits such as access to government-controlled resources, and intangible benefits such as political support and goodwill. Such resources can be accessed through managerial political ties (Guo et al. 2014; Li and Zhang 2007; Peng and Luo 2000).

In this paper, we address the sources of competitive advantage and firm performance in the Russian hotel industry through the lens of chain affiliation as a strategic choice of the hotel firm. Hotel chain is an organizational form characteristic to the hospitality industry. Ingram and Baum (1997, p. 68) define hotel chains as "collections of service organizations, doing substantially the same thing that are linked together into a larger organization". The chain typically consists of component hotels, and centralized units responsible for functions such as 
distribution or marketing (Ingram and Baum 1997). Hence, the potential benefits that chain affiliation offers to its members include access to superior industryspecific resources and capabilities, embodied in the centralized functions and in managerial practices.

Correspondingly, hospitality research considers chain affiliation as one of the key determinants that explain hotel performance (Sainaghi 2010). Most of existing research has identified a positive relationship between chain affiliation and hotel performance, as chain affiliation may contribute to survival of hotels (Ingram and Baum 1997) or lead to superior financial performance (e.g., Chung and Kalnins 2001; Menicucci 2018; Mitsuhashi and Yamaga 2006). Nevertheless, this research has paid little explicit attention to the mechanisms through which chain affiliation may improve performance. In this paper, we investigate the chain affiliation-performance relationship through the lens of competitive advantage. In particular, we maintain that from the RBV, chain affiliation provides the hotel firm with resources and capabilities to build market-based forms of competitive advantage through differentiation and cost leadership.

The basis advantage of hotel chains over independent hotels is their ability to form identifiable image, standardized hospitality product and guaranteed service quality through transfer of knowledge and best practices (Ingram and Baum 1997). Moreover, the possibility to use the brand of the chain in marketing is an incentive for independent hotels to join the chain (Dahlstrom et al. 2009). Well-established brands are intangible assets that serve as a source of strategic advantage and contribute to financial performance through higher margins (O'Neill and Mattila 2006). In the context of emerging economies such as Russia, where the industry standards in terms of, for example service quality or branding are underdeveloped (Karhunen 2008; Sheresheva et al. 2016), we hypothesize that the knowledge and resources accessible through chain affiliation would help hotels to develop a superior service product, and thus serve as a source for differentiation advantage.

Hypothesis 1: Differentiation advantage is a more important factor of performance for chain affiliated hotels than for independent ones.

Moreover, we maintain that chain affiliation would serve as a source for cost advantage for the hotel firm. This is because the member hotels benefit from the chain's knowledge on the effective organization of business processes such as human resource management, and can save costs through economies of scale (Ingram and Baum 1997) through the use of centralized supply, marketing and information systems of the chain (Mitsuhashi and Yamaga 2006). Furthermore, the chain membership offers the hotel the possibility to use an existing, well established brand in marketing, which is a more cost-effective way than launching and promoting one's own brand on the market (Dahlstrom et al. 2009; O'Neill and Mattila 2006; Sheresheva et al. 2016). In sum, we maintain that chain affiliation provides the hotel firm with resources and capabilities to build competitive advantage via cost leadership, and make the following hypothesis: 
Hypothesis 2: Cost advantage is a more important factor of performance for chain-affiliated hotels than for independent ones.

Our first two hypotheses focused on industry-specific knowledge and resources as source of market-based advantage. At the same time, we maintain that local knowledge and non-market resources are important sources for competitive advantage in emerging economies, and apply the institution-based view on business strategy to formulate our final hypotheses.

In emerging economies, relations to institutional constituents are an important part of business strategy (Peng and Luo 2000). Such relations help coping with excessive red tape and bureaucracy that are characteristic to operating environments in emerging economies (Karhunen et al. 2018). The ability to effectively comply with regulatory requirements is particularly important for the hotel sector, where the nature of operations involving accommodation of individuals and selling of alcoholic beverages require numerous licenses and permits (Sharma and Christie 2010). Therefore, we argue that in addition to market-based differentiation and cost advantages, institutional advantage ( $\mathrm{Li}$ and Zhou 2010) would be an important determinant of performance in the Russian hotel industry.

We support this argument by the research evidence on the positive performance implications of non-market strategies (Guo et al. 2014; Li and Zhang 2007; Peng and Luo 2000). Researchers have identified institutional support (Guo et al. 2014) or resource acquisition (Wang et al. 2013) as mediators of political ties-performance relationship. Further, Tang et al. (2019) showed that privately owned firms may use managerial ties (including political ones) to improve their competitive position visá-vis governmental and foreign-owned firms that are considered to have superior resources. In this study, we maintain that institutional advantage is a particularly important determinant of performance for independent hotels, which do not have the market-based advantages of chain affiliation. In addition, affiliation to a foreign chain with strict governance policies may constrain the hotel management's ability to establish and maintain ties with institutional constituents in an environment such as Russia, where the line between relationship management and corruption is easily crossed (see, e.g., Karhunen et al. 2018). Moreover, scholarship on political ties and firm performance has reached a consensus that political ties constitute a doubleedged sword with respect to firm performance, i.e., political ties have the potential to improve performance, but also run the risk of eroding performance (Wang et al. 2019). Hence, the firm needs to be able to evaluate the value of political ties, and know how to deploy them a as resource. Our third hypothesis thus reads as follows:

Hypothesis 3: Institutional advantage is a more important factor of performance for independent hotels than for chain affiliated ones. 


\section{Methodology}

\subsection{Sample}

To test our hypotheses, we conducted a survey to hotel enterprises located in the two largest cities of Russian Federation, the capital Moscow and St. Petersburg. Russia is a rather typical emerging economy and identified as such by all major investment classification sources (Marquis and Raynard 2015). When considering economic, legal, social and governance aspects, Russia represents a rather classical case of an emerging economy (see Shleifer and Treisman 2005). Although business regulation in Russia has become less complex in recent years (World Bank 2021), problems characteristic to emerging economies such as corruption associated with the enforcement of regulation still persist (Transparency International 2021). The cities of Moscow and St. Petersburg are business, scientific and cultural centers of Russia, which makes them attractive both for leisure and business tourism. At the same time, they are among the most challenging institutional environments within Russia for doing business (World Bank 2012).

We started our empirical study by designing an English-language version of the survey questionnaire and then asking an independent translator to translate it into Russian and then back into English. To ensure the content and face validity of the survey measures, we mainly relied on existing scales in formulating the questions. Next, we finalized the questionnaire with a Russian research agency that performed the data collection and piloted the questionnaire with 20 hotel managers. The piloting revealed that the respondents had understood very well the survey items and that range of responses for most items was reasonably diverse.

We identified the hotel population for the survey by using two major hotel booking sites, Trivago and Hotels.com. We selected these two sites as they provide the most comprehensive selection of hotels in Russia, and also give such information on the properties that we needed to construct our sample.

At the first step, we searched for all properties in the category of "hotels", resulting in total 701 entries (398 in Moscow and 303 in St. Petersburg). At the second step, we excluded properties that (1) classify as mini-hotels (having 15 or less rooms) as they are subject to their own legislation, (2) provide only bed and breakfast, (3) have no functioning website, or (4) are apartments although booking sites classify them as hotels. This resulted in excluding 298 properties (129 In Moscow and 169 in St. Petersburg). Hence, the number of hotels meeting the criteria of our study was 403 properties, which formed our target population and thus the sample.

In each hotel, a senior manager served as the key informant, as these managers were expected to be familiar with their hotel's competitive strategy and performance. We subcontracted the Russian research agency with its trained interviewers to conduct the survey via personal contact, which is the research strategy that will most likely generate valid information in emerging economies ( $\mathrm{Li}$ and Zhou 2010). The survey was implemented in November 2014-January 2015. Potential respondents were first contacted via telephone to invite them to participate in the research, 
resulting in 162 senior managers agreeing to participate. They were then interviewed onsite, which means a response rate of $40 \%$.

The majority of the respondent hotels represent the mid-range segment, i.e., 3 -star (49\%) and 4-star (36\%) properties. The size of the hotels varies from 16 to 930 rooms, the average number of rooms being 133. Majority are independent hotels, as only a third belongs to a hotel chain. About $80 \%$ of the hotels are managed by the property owner. The hotel properties are in most cases in private Russian ownership, but a third of them have at least some municipal or state ownership and $17 \%$ at least some foreign ownership. 54 hotels (33\%) are located in St. Petersburg and Leningrad region while 108 hotels (67\%)-in Moscow and Moscow region.

\subsection{Variables}

\subsubsection{Dependent Variable}

Our dependent variable is Revenues per Available Room (RevPAR), which is the most commonly used productivity measure in the hotel industry (Brown and Dev 1999) and frequently applied in academic research on hotel performance (Sainaghi 2010). In this study, we apply it as a subjective variable measuring the respondent's perception on its Revenues per Available Room compared to its competitors on an ordinal scale of 1-7 (from "much below" to "much above"). Managers' perceptions of performance is an appropriate measure of actual performance, as several studies have affirmed a high and statistically significant relationship between perceived and actual measures of performance (recently e.g., Day et al. 2015). Similar measure of performance has been also used in a recent study of Wilke et al. (2019).

The decision to use a perceptual financial measure instead of objective measures is further justified by our research context. The lack of transparency and financial misreporting are common features of firms in emerging economies, particularly Russia and China (Li et al. 2014). Therefore, the quality of accounting-based financial indicators is often questionable. This problem also relates to the complex governance structures of the Russian industries, where independent businesses are often organized into business groups or holdings for taxation purposes (see, e.g., Ledyaeva et al. 2015). This makes it challenging to attain hotel-level accounting data.

\subsubsection{Explanatory Variables}

We consider three dimensions of competitive advantage-differentiation advantage, cost advantage and institutional advantage, adapted from Li and Zhou (2010). We measured them by first components of factor analysis of respective seven-point items ${ }^{1}$ as reported in Table 1.

\footnotetext{
${ }^{1}$ Each respondent was expected to comment on the statements on competitive position of her hotel in the past three years using 7 -point scales from $1=$ completely disagree to $7=$ completely agree.
} 


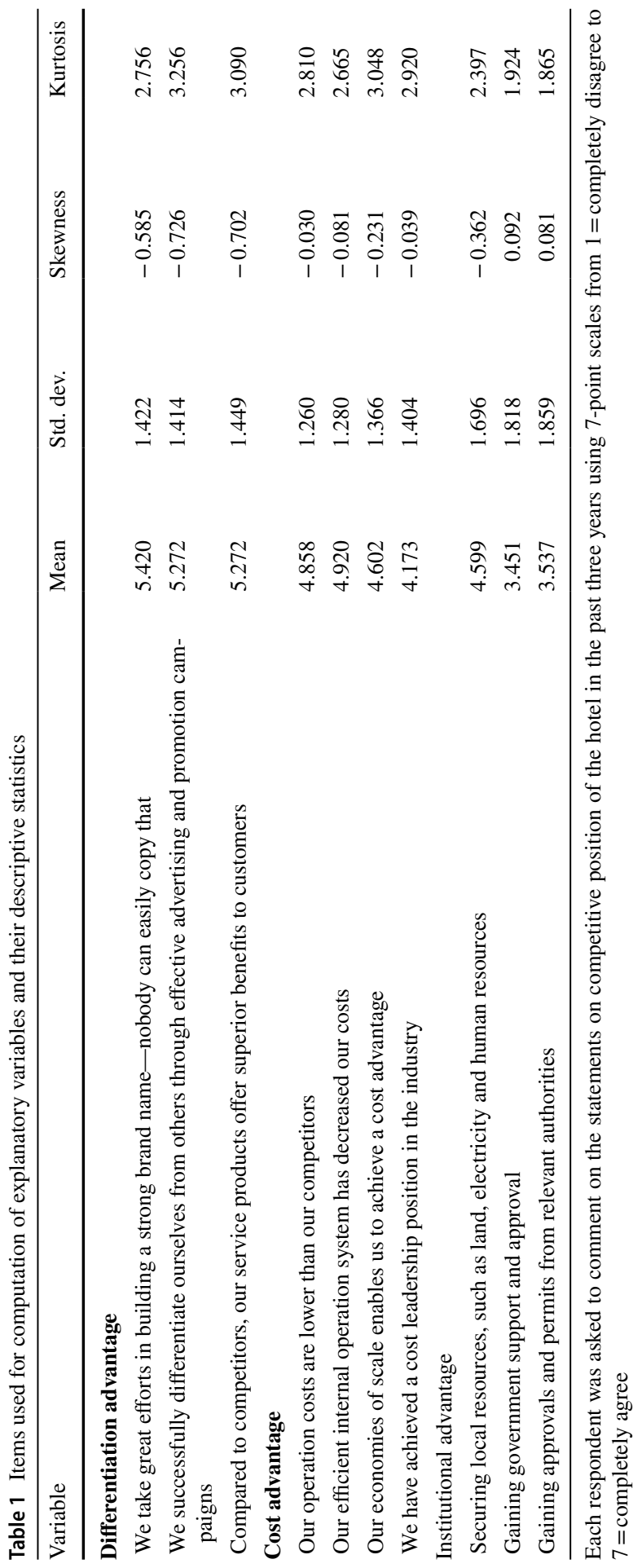


As can be seen from the table, the measures of normality, skewness and kurtosis suggest that the items' distributions do not depart substantially from normal distribution.

In Table 2 we report eigenvalues, factor loadings, Kaiser-Meyer-Olkin (KMO) measure, Bartlett's test of sphericity, Cronbach's alpha and Average Variance

Table 2 Factor analysis: Construct validity

Differentiation advantage

FE1*

FE2

FE3

FL11: We take great efforts in building a strong brand name-nobody can easily copy that

FL12: We successfully differentiate ourselves from others through effective advertising and promotion campaigns

FL13: Compared to competitors, our service products offer superior benefits to customers

$\mathrm{KMO}^{\gamma}$

$\mathrm{BTS}^{\alpha}$

$\mathrm{CA}^{\beta} / \mathrm{AVE}^{\eta}$

Cost advantage

FE 1

FE 2

FE 3

FE 4

FL11: Our operation costs are lower than our competitors

FL12: Our efficient internal operation system has decreased our costs

FL13: Our economies of scale enables us to achieve a cost advantage

FL14: We have achieved a cost leadership position in the industry

$\mathrm{KMO}^{\gamma}$

$\mathrm{BTS}^{\alpha}$

$\mathrm{CA}^{\beta} / \mathrm{AVE}^{\eta}$

Institutional advantage

FE 1

FE 2

FE 3

FL11: Securing local resources, such as land, electricity and human resources

FL12: Gaining government support and approval

FL13: Gaining approvals and permits from relevant authorities

$\mathrm{KMO}^{\gamma}$

$\mathrm{BTS}^{\alpha}$

$\mathrm{CA}^{\beta} / \mathrm{AVE}^{\eta}$
1.895

$-0.08$

$-0.159$

0.849

0.767

0.765

0.715

$\mathrm{X}^{2} 225.188$; sig. 0.000

$0.858 / 0.632$

2.47

$-0.005$

$-0.11$

$-0.141$

0.755

0.799

0.852

0.731

0.816

$\mathrm{X}^{2} 325.927$; sig. 0.000

$0.873 / 0.618$

1.852

$-0.025$

$-0.111$

0.469

0.905

0.901

0.604

$\mathrm{X}^{2} 259.136$; sig. 0.000 $0.807 / 0.617$

*FE1 denotes Eigenvalue of factor 1, etc.; **FL11 denotes Factor 1 loading of 1 st item, etc.; ${ }^{\gamma} \mathrm{KMO}$ denotes Kaiser-Meyer-Olkin measure of sampling adequacy; ${ }^{\alpha}$ BTS denotes Bartlett's test of sphericity; ${ }^{\beta} \mathrm{CA}$ denotes Cronbach's alpha; ${ }^{\eta} \mathrm{AVE}$ denotes Average variance extracted 
Extracted (AVE) for the three constructs. The results for KMO and Bartlett's test confirm that the sampling is adequate. Cronbach's alpha coefficients, all above 0.8 , suggest that the items within constructs have rather high internal consistency. Finally, AVEs, all above 0.6, confirm convergent validity of the constructs.

\subsubsection{Control Variables}

To account for extraneous variables that might influence a firm's performance, we included standard hotel performance factors used in hospitality research (Sainaghi 2010). Our controls include Natural logarithm of number of rooms, Natural logarithm of number of employees, The year when the hotel started its operation, Star rating and The share of outsourced employees in the total number of staff.

In addition to the continuous variables, we have included several blocks of dummy variables. First block controls for hotels' location. St. Petersburg dummy controls for the hotel's location in the city of St. Petersburg or Leningrad region (reference group is Moscow city and Moscow region). Province dummy equals to one if a hotel is located in a suburb/region of St. Petersburg or Moscow. City center dummy equals to one if a hotel is situated in the down town, i.e., within $1.5 \mathrm{~km}$ radius from the city center.

Second block of dummies control for management related issues. Management contract dummy controls the difference between contract-managed and owner-managed hotels (the latter being the reference group). Private ownership dummy equals to one if state ownership is less than $50 \%$ (reference being state owned hotels with state ownership higher than 50\%). Finally, Foreign general manager dummy equals to one if the hotel's general manager does not have Russian citizenship.

At last, Dummy for hotel's chain affiliation (equals to one if a hotel is part of a chain and zero otherwise) is introduced to test hypotheses 1-3.

All our data is retrieved from the original survey data collected for the study. A general concern in survey based empirical research is the so called common method bias (CMB) which arises from "variance that is attributable to the measurement method rather than to the constructs the measures represent" (Podsakoff et al. 2003), which can lead to either Type I and Type II errors in statistical deductions. While there is a debate on the seriousness of the problem, concerning, for example, the superiority of other-reports to self-reports (Conway and Lance 2010), it should be acknowledged. $\mathrm{CMB}$ is a potential problem in our case because all of our variables are self-reported by same respondents and there is no lag between the performance and explanatory variables. However, we also think that there are some attenuating factors at play. First, our key variable of interest: Competitive advantage, is very difficult to measure objectively (especially institutional advantage) which argues for self-reporting. Attempt to capture institutional advantage through other sources might induce measurement error more severe than the potential CMB. Secondly, even though our control variables are also self-reported, they are arguably objective in nature (such as amount of employees and rooms, start year, classification) and thus should not be affected by the methodology or respondent. Thirdly, all our explanatory variables are quite static firm characteristics. Hence, there is no clear 
intuition why a lag would be needed to pick up the performance effect of the explanatory variables.

\subsubsection{Descriptive Analysis of the Variables}

In Table 3 we present basic descriptive statistics of all variables included in our empirical model. Table 4 presents additional descriptive statistics of categorical variables.

The mean value of our dependent variable, Revenues per Available Room is 4.74 with a standard deviation of 0.98 . Hence, on average, respondents tended to evaluate their hotels' performance being above of the performance level of their main competitors. Indeed, from Table 4 we can see that $61 \%$ of respondents have chosen numbers above four when they were asked to assess the performance of their hotels relative to competitors from one (much below) to seven (much above). The values of skewness and kurtosis of the dependent variable $(-0.35$ and 2.95 , respectively) allow us to assume that it has normal distribution.

The mean number of rooms is 133.5 with a range between 16 and 930. The mean number of employees is 70.6 with a range between 6 and 500. In general, these numbers suggest that most hotels tend to be relatively small. Indeed, from

Table 3 Descriptive statistics of variables

\begin{tabular}{|c|c|c|c|c|c|c|c|}
\hline Variable & N. obs. & Mean & Std. dev. & Min. & Max. & Skewness & Kurtosis \\
\hline Revenue per room & 159 & 4.74 & 0.98 & 2 & 7 & -0.35 & 2.95 \\
\hline Number of rooms & 162 & 133.51 & 140.27 & 16 & 930 & 2.39 & 10.95 \\
\hline Number of rooms, natural logarithm & 162 & 4.45 & 0.95 & 2.77 & 6.84 & 0.19 & 2.11 \\
\hline Number of employees & 157 & 70.62 & 77.15 & 6 & 500 & 2.49 & 10.74 \\
\hline $\begin{array}{l}\text { Number of employees, natural } \\
\text { logarithm }\end{array}$ & 157 & 3.81 & 0.93 & 1.79 & 6.21 & 0.3 & 2.31 \\
\hline $\begin{array}{l}\text { Year when the hotel started its } \\
\text { operation }\end{array}$ & 161 & 1999.24 & 18.57 & 1875 & 2014 & -3.11 & 16.35 \\
\hline Star rating & 159 & 3.49 & 0.75 & 2 & 5 & 0.31 & 2.7 \\
\hline $\begin{array}{l}\text { Share of outsourced employees in } \\
\text { total number of staff }\end{array}$ & 155 & 9.74 & 12.93 & 0 & 60 & 1.38 & 4.7 \\
\hline St. Petersburg dummy & 162 & 0.33 & 0.47 & 0 & 1 & 0.71 & 1.5 \\
\hline Province dummy & 161 & 0.17 & 0.38 & 0 & 1 & 1.72 & 3.96 \\
\hline City center dummy & 162 & 0.10 & 0.30 & 0 & 1 & 2.69 & 8.24 \\
\hline Management contract dummy & 159 & 0.17 & 0.38 & 0 & 1 & 1.76 & 4.09 \\
\hline Private ownership dummy & 162 & 0.90 & 0.31 & 0 & 1 & -2.58 & 7.65 \\
\hline Foreign general manager dummy & 158 & 0.06 & 0.23 & 0 & 1 & 3.82 & 15.62 \\
\hline Dummy for hotel's chain affiliation & 162 & 0.31 & 0.47 & 0 & 1 & 0.8 & 1.64 \\
\hline Differentiation advantage & 162 & 0.00 & 0.90 & -3.08 & 1.18 & -0.62 & 3.14 \\
\hline Cost advantage & 161 & 0.00 & 0.92 & -2.96 & 1.88 & -0.07 & 3.24 \\
\hline Institutional advantage & 162 & 0.00 & 0.94 & -1.41 & 1.88 & 0.09 & 1.95 \\
\hline
\end{tabular}


Table 4 Descriptive statistics of categorical variables

\begin{tabular}{|c|c|c|c|}
\hline Variable & Frequency & Percent & Cumulative percent \\
\hline \multicolumn{4}{|l|}{ Revenue per room } \\
\hline Much below (1) & 0 & $0 \%$ & $0 \%$ \\
\hline (2) & 3 & $2 \%$ & $2 \%$ \\
\hline (3) & 12 & $8 \%$ & $9 \%$ \\
\hline (4) & 46 & $29 \%$ & $38 \%$ \\
\hline (5) & 62 & $39 \%$ & $77 \%$ \\
\hline (6) & 34 & $21 \%$ & $99 \%$ \\
\hline Much above (7) & 2 & $1 \%$ & $100 \%$ \\
\hline \multicolumn{4}{|l|}{ Star rating } \\
\hline $1 *$ & 0 & $0 \%$ & $0 \%$ \\
\hline $2^{*}$ & 9 & $6 \%$ & $6 \%$ \\
\hline $3^{*}$ & 78 & $49 \%$ & $55 \%$ \\
\hline $4^{*}$ & 57 & $36 \%$ & $91 \%$ \\
\hline $5^{*}$ & 15 & $9 \%$ & $100 \%$ \\
\hline \multicolumn{4}{|c|}{ St. Petersburg dummy } \\
\hline 1 & 54 & $33.33 \%$ & $33.33 \%$ \\
\hline 0 & 108 & $66.67 \%$ & $100 \%$ \\
\hline \multicolumn{4}{|l|}{ Province dummy } \\
\hline 1 & 28 & $17.39 \%$ & $17.39 \%$ \\
\hline 0 & 133 & $82.61 \%$ & $100 \%$ \\
\hline \multicolumn{4}{|c|}{ City center dummy } \\
\hline 1 & 16 & $9.88 \%$ & $9.88 \%$ \\
\hline 0 & 146 & $90.12 \%$ & $100 \%$ \\
\hline \multicolumn{4}{|c|}{ Management contract dummy } \\
\hline 1 & 27 & $16.98 \%$ & $16.98 \%$ \\
\hline 0 & 132 & $83.02 \%$ & $100 \%$ \\
\hline \multicolumn{4}{|c|}{ Private ownership dummy } \\
\hline 1 & 145 & $89.51 \%$ & $89.51 \%$ \\
\hline 0 & 17 & $10.49 \%$ & $100 \%$ \\
\hline \multicolumn{4}{|c|}{ Foreign general manager dummy } \\
\hline 1 & 9 & $5.56 \%$ & $5.56 \%$ \\
\hline 0 & 149 & $91.98 \%$ & $100 \%$ \\
\hline \multicolumn{4}{|c|}{ Dummy for hotel's chain affiliation } \\
\hline 1 & 51 & $31.48 \%$ & $31.48 \%$ \\
\hline 0 & 111 & $68.52 \%$ & $100 \%$ \\
\hline
\end{tabular}

Fig. 1 below we can see that 94 hotels in the sample (71\%) have less than 107 rooms. In addition, 91 hotels $(82.6 \%)$ have less than 55 employees.

We can further notice that the variables of number of rooms and employees have rather high values of skewness and kurtosis. Hence, before including them 


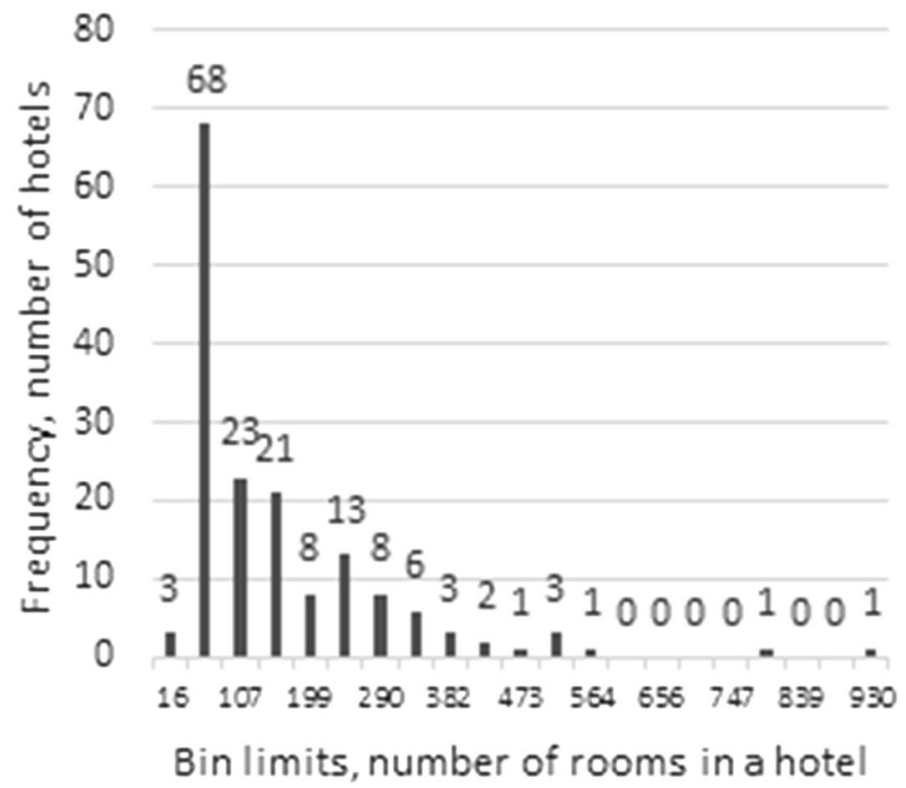

Fig. 1 Distribution of hotels by number of rooms

into the estimation model we performed their logarithmic transformation that helped to normalize them.

Most hotels (130, around 81\%) in the sample were established in 2000s while the oldest one was established in 1875. The star rating of the sampled hotels range from 2 to 5 with mean value of 3.5. The majority of the respondent hotels represent the mid-range segment, i.e., 3-star (49\%) and 4-star (36\%) properties.

Finally, majority of sampled hotels are located in Moscow city or region (67\%), are not chain-affiliated (i.e., independent; 68.5\%), have general manager with Russian citizenship (92\%), and are owner-managed hotels (83\%).

In Table 5, we present the correlation matrix of explanatory and control variables included in the proposed empirical model.

We can notice that our indicators of Cost and Differentiation advantages correlate with each other rather significantly (correlation coefficient equals to 0.58). To address this issue we employed a blockwise hierarchical approach to test our hypotheses (details are provided below). Moreover, the correlation coefficient between Natural logarithm of number of rooms and Natural logarithm of number of employees equals to 0.84 . Hence, we decided to remove the latter variable (as it has slightly fewer observations than the former variable) from the model. 


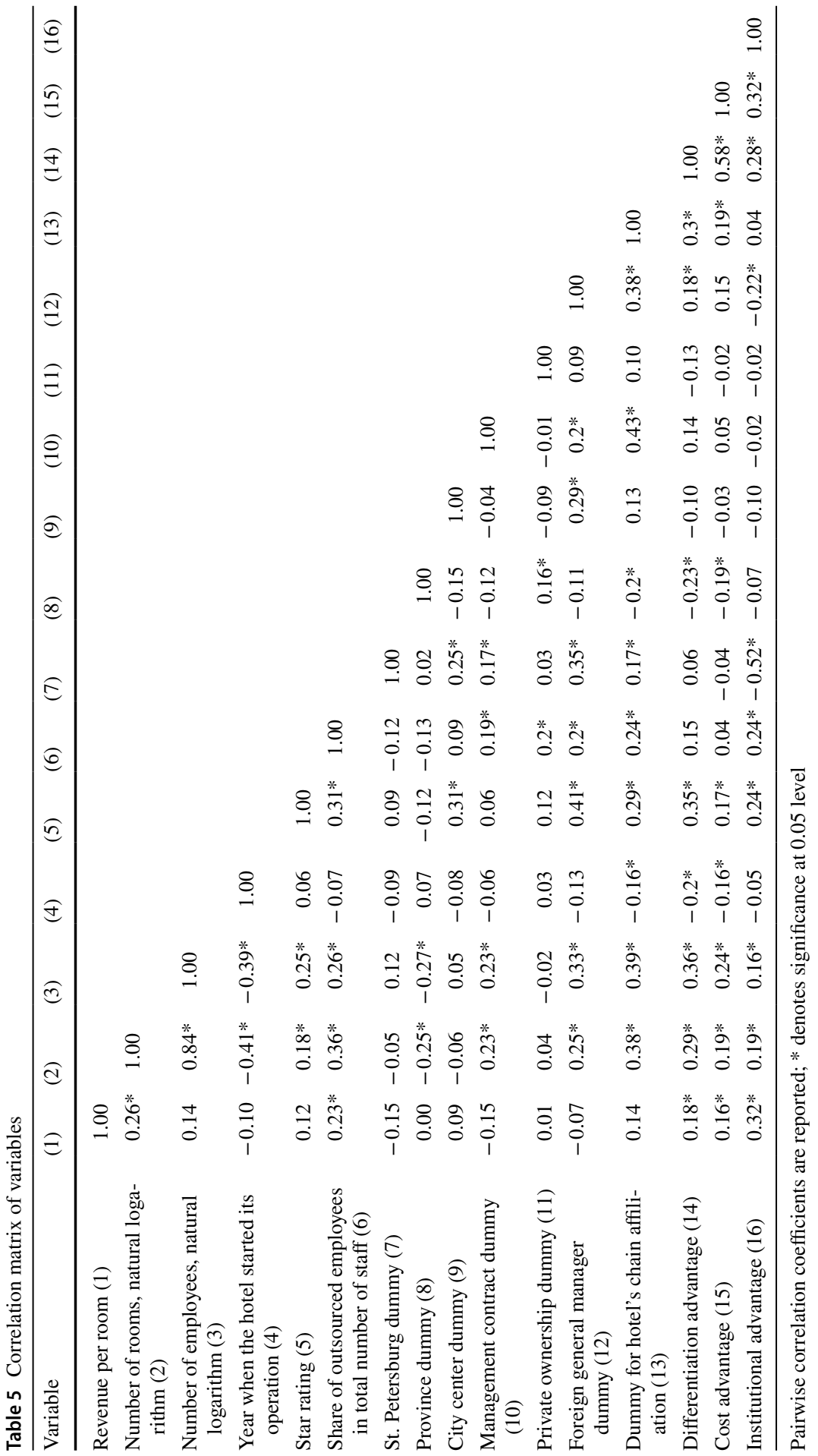




\subsection{Estimation Method}

The dependent variable in this study is ordinal. It reflects the respondent's view on its Revenue per available room compared to its competitors on an ordinal scale of 1-7 (from "much below" to "much above"). Typically, the ordinal data modelling problem is motivated by the latent regression perspective, as mathematically defined in Eq. (1):

$$
Y=j \quad \text { if } \quad a_{j-1}<Y * \leq a_{j}
$$

where $\mathrm{Y}^{*}$ is a continuous latent variable that is assumed to underlie the observed ordinal data. More specifically, $Y *=\beta^{\prime} X+\in$ and $\mathrm{X}$ is a vector of explanatory variables, $\beta$ is a vector of coefficients and $\in$ is an error term. $\mathrm{j}$ is an ordinal response. $a$ is a set of cutpoints of the continuous scale for $\mathrm{Y}^{*}$. In other words, $\mathrm{Y}$ is observed to be in category $\mathrm{j}$ when the latent variable falls in the $j$ th interval.

To model ordinal dependent variable, we apply the logit transformation to the cumulative probabilities, as defined in Eq. (2):

$$
\log \text { it }[P(Y \leq j)]=\log (P(Y \leq j) / 1-P(Y \leq j)) .
$$

A typical model for the cumulative logits is presented in Eq. (3):

$$
\log i t[P(Y \leq j)]=a_{j}+\beta_{1} x_{1}+\beta_{2} x_{2}+\cdots+\beta_{n} x_{n}=a_{j}+\beta^{\prime} X,
$$

where $\mathrm{j}=1, \ldots, \mathrm{c}-1$; $\mathrm{c}$ is the total number of categories. $x_{n}$ are $\mathrm{n}$ explanatory variables; $\beta_{n}$ are corresponding coefficients.

Equation (3) implies that for different $\mathrm{j}$, the explanatory variables have a common effect, as reflected by the common $\beta$. It can be illustrated by the following example. Suppose we have two points from the explanatory variables, $X_{a}$ and $X_{b}$ (note that $\mathrm{X}$ is a vector), then

$$
\log i t\left[P\left(Y \leq j \mid X_{a}\right)\right]-\log i t\left[P\left(Y \leq j \mid X_{b}\right)\right]=\beta^{\prime}\left(X_{a}-X_{b}\right) .
$$

Equation (4) indicates that the log odds ratio is proportional to the distance between these two points. This proportionality remains constant across different categories. Due to this property, the model in Eq. (3) is often referred to a "proportional odds model". This model has been extensively studied and widely used in the literature (Agresti 2010; Greene and Hensher 2010). Thus, we also employ it in our paper.

Because our hypotheses suggest interaction terms composed of competitive advantages' indicators and Dummy for chain affiliation, we utilize a moderated regression analysis for testing these effects (Jaccard et al. 1990). As was already pointed out above, in order to count for rather high correlation between the types of competitive advantage we further employed a blockwise hierarchical approach to test our hypotheses (cf. Elvira and Cohen 2001, p. 599; McGrath 2001, p. 125). This blockwise procedure resulted in three additional models. 


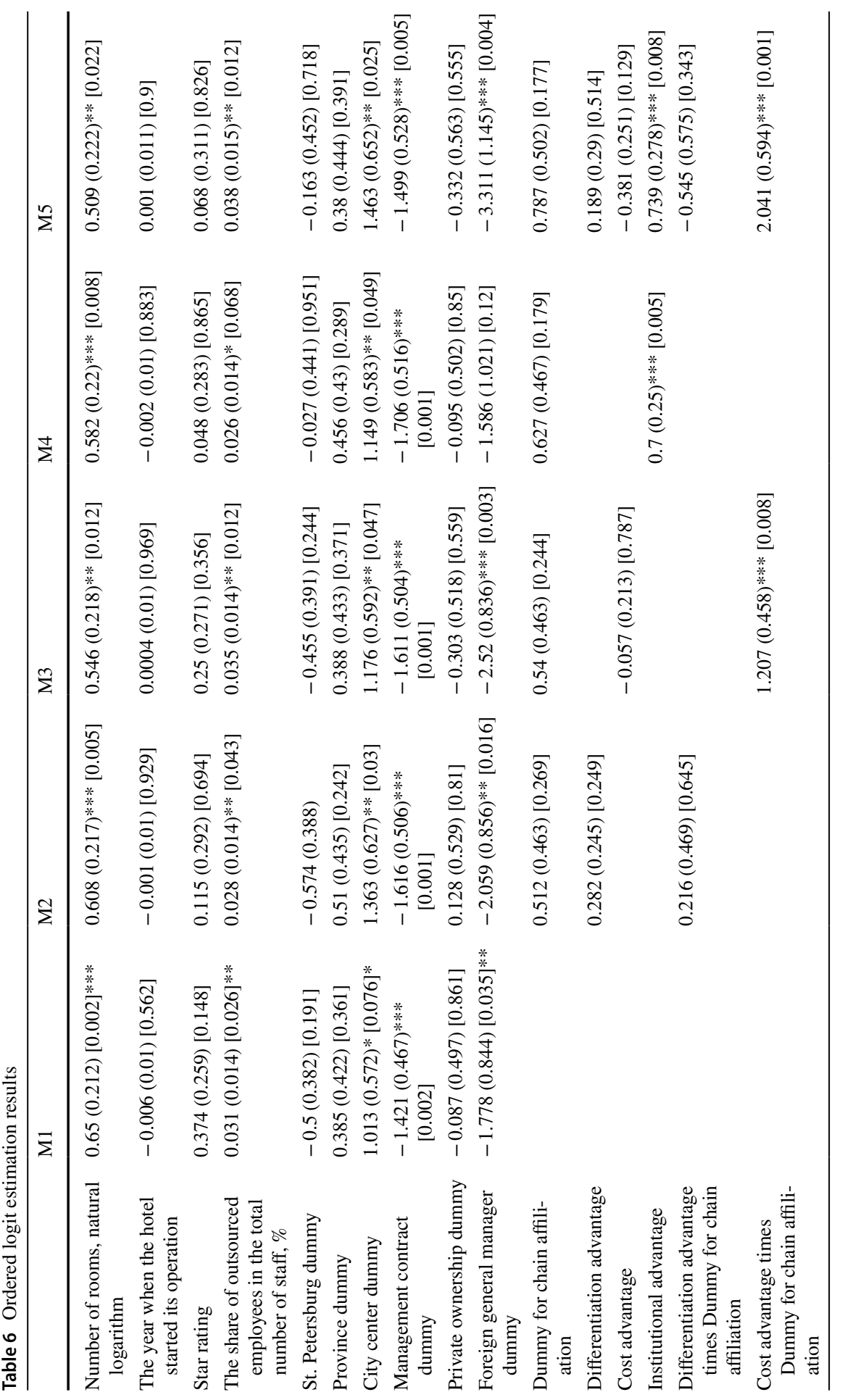




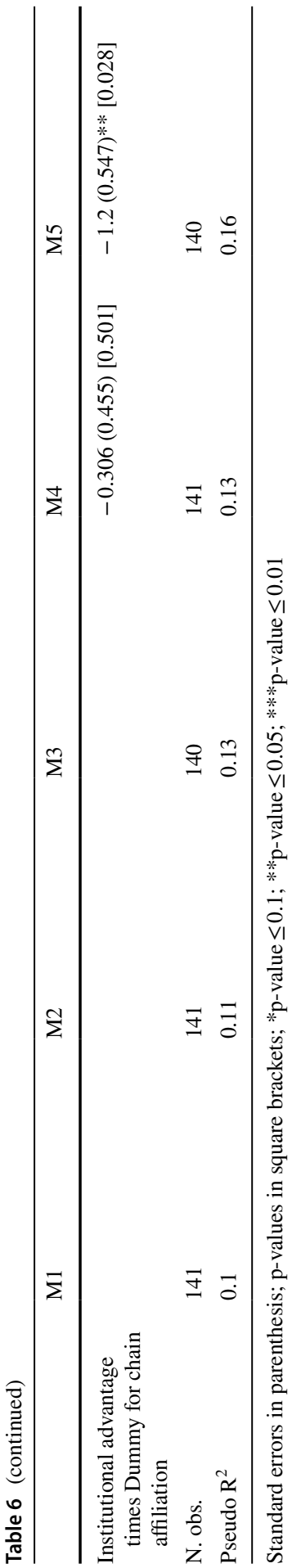




\section{Results}

In Table 6 we report ordered logit estimation results.

Table 6 contains our five regression models. In Model 1 we included only the control variables. The coefficients of five controls are statistically significant. In particular, on the one hand, Natural logarithm of number of rooms, The share of outsourced employees and City center dummy is positively related to performance (p-values equal to 0.002, 0.026 and 0.076, respectively). On the other hand, Management contract dummy and Foreign general manager dummy are negatively related to performance (p-values equal to 0.002 and 0.035 , respectively).

Model 2 tests Hypothesis 1 that suggests that differentiation advantage is a more important factor of performance of chain affiliated hotels than of independent ones. This model contains control variables plus Chain dummy, Differentiation advantage variable and their interaction term. The results for control variables remain virtually the same as in Model 1. None of the coefficients of the included explanatory variables is statistically significant. Hence, we do not find supportive evidence for our Hypothesis 1 .

In Model 3 we test Hypothesis 2 that suggests that cost advantage is a more important factor of performance of chain-affiliated hotels than of independent ones. This model includes control variables plus Chain dummy, Cost advantage variable and their interaction term. Once again, the results for control variables remain virtually the same as in Models 1 and 2. The coefficient of the interaction term between Chain dummy and Cost advantage variable is positive and highly statistically significant $(\mathrm{p}$-value $=0.008$ ) that gives firm support for our Hypothesis 2 .

Our final hypothesis is tested in Model 4. Hypothesis 3 suggests that institutional advantage is a more important factor of performance of independent hotels than of chain affiliated ones. This model includes control variables plus Chain dummy, Institutional advantage variable and their interaction term. The results for control variables remain virtually the same as in Models 1, 2 and 3. Though the coefficient of the Institutional advantage variable is positive and highly statistically significant ( $p$-value $=0.005)$, the coefficient of its interaction term with Chain dummy is not statistically significant (albeit it is negative as expected). In general, these results point to the conclusion that Institutional advantage is equally important for the performance of independent and chain affiliated hotels.

Finally, Model 5 includes all the control and explanatory variables. The results for control variables remain virtually the same as in previous models. In general, the results for the explanatory variables are rather similar to the results in Models 2-4, however, the full model gives support for the Hypothesis 3. In particular, the coefficient of the interaction term between Institutional advantage variable and Chain dummy is negative and statistically significant ( $\mathrm{p}$-value $=0.028$ ). This indicates that Institutional advantage is significantly less important factor for performance of chain-affiliated hotels compared to independent ones.

It should be further noted that the coefficients in ordered logit model should be interpreted in a proper way. In particular, standard interpretation of the ordered logit coefficient is that for a one-unit increase in the predictor, the response variable level 
is expected to change by its respective regression coefficient in the ordered log-odds scale while the other variables in the model are held constant. E.g., in Model 4 of Table 6, a one unit increase in Institutional advantage measure would result in 0.411 unit increase in the ordered log-odds of being in a higher performance category while the other variables in the model are held constant.

\section{Discussion}

Our paper intended to contribute to the debate on firm strategy as determinant of firm performance in emerging economies by providing an industry-level analysis. In doing so, it adds to strategy research in emerging economies that has paid scant attention to the fact that firms formulate their strategies and deploy resources to gain advantage over their competitors in the same industry (Acquaah and Chi 2007). It further enriches the knowledge on the performance implications of non-market strategies in emerging economies by comparing them with those of market-based ones, and linking them to different business models. Finally, our study offers a new empirical context for the strategy research on emerging economies, which is dominated by studies on Chinese enterprises (Fan et al. 2013).

Our study integrated the RBV and institutional approach on firm strategy to investigate performance implications of market-based strategies, eventually leading to differentiation advantage or cost leadership as suggested by the RBV (Barney 1991), and non-market strategies that manifest in institutional advantage (Li and Zhou 2010). We further analyzed how chain affiliation as an important strategic choice and one of the key industry-specific determinants for hotel performance, influences the strategy-performance nexus in the Russian emerging hospitality industry.

We hypothesized first, that chain affiliation would lead to superior performance through two kinds of market-based advantages: differentiation advantage and cost advantage. This would be due to the access to industry-specific resources and capabilities possessed by the chain. Interestingly, our empirical analysis suggested that the competitive edge of chain-affiliated hotels indeed arises from market-based advantage, but only in terms of cost advantage. In contrast to our expectations, we found that differentiation advantage is not an important factor of performance for chain-affiliated hotels. This indicates that chain-affiliated hotels in Russia would not be fully able to transform the benefits of chain affiliation, including the possibility to use Western brands that are generally considered as more prestigious in the emerging economy context (Huddleston et al. 2001; Manrai et al. 2001; Pham and Richards 2015), into competitive advantage.

We explain this finding by characteristics of emerging economies as an institutional context. In particular, chain membership can be a strategic disadvantage for the hotel firm, if the chain owner has developed its strategy and business concept in a different institutional environment (Brookes and Roper 2010; Ingram and Baum 1997; see also Brouthers et al. 2008 on the contextuality of resources). For example, in emerging economies such as Russia, the hospitality industry is still underdeveloped and the concept of hotel chain is not as established as in developed market economies (Karhunen 2008; Sheresheva et al. 2016). Therefore, local hotels may not 
be able to meet the standards of hotel chains in terms of guaranteed service quality and identifiable image (Ingram and Baum 1997) that would be the building blocks for differentiation advantage. This is linked to the poor quality of human resources in emerging economies, demonstrating in professional skills and service attitude (Andrades and Dimanche 2017; Sharma and Christie 2010). Hence, the international brand as such may not provide competitive advantage, if it is not accompanied with appropriate service level and customer experience.

Second, we hypothesized a positive relationship between institutional advantage and performance for independent hotels. Such knowledge is needed to cope with state regulation, which in emerging economies is a burdensome task for firms. This is due to excessive bureaucracy and cumbersome procedures in, for example, getting permits and licenses. Our results supported this hypothesis, further pointing to the direction that chain affiliation may be a strategic constraint in emerging economies. In particular, independent hotels may have more freedom in their policies in relation to institutional constituents, and less strict governance standards. Institutional advantage, when understood as consisting of benefits such as access to governmentcontrolled resources or political goodwill (Li and Zhou 2010), often implies a twoway exchange between firms and authorities (Karhunen et al. 2018). Hence, governance standards required by chain affiliation may constrain hotel firms' opportunities to establish close relations with authorities and thereby build institutional advantage. This finding demonstrates the general importance of managerial freedom as competitive strength of independent firms vis-á-vis chain affiliated ones (Beaver and Prince 2004; Holverson and Revaz 2006).

As all research, our study has its limitations that at the same time provide avenues for future research. We focused empirically on one country, which may limit the generalizability of our findings to other geographic contexts. Future research might analyze the strategy-hotel performance nexus in other countries. Our study also applied chain affiliation as a firm-level proxy for access to industry-specific knowledge and assets, but did not measure the costs associated with the acquisition of managerial and marketing expertise via chain affiliation. We acknowledge that accounting for these costs might eventually dilute the cost advantage of hotels, and also that access to such industry-specific expertise may be provided also by the recruitment of experienced management. Hence, future research might investigate managerial characteristics as source of hotel competitive advantage, and also consider how factors such as entrepreneurial spirit that is associated with independent hotels is related to competitive strategies and performance.

Finally, we based our theorization on the idea that standardization of the service product and business processes is a key strategic asset for firms. Future research might study how competitive advantage of chain-based businesses is shaped in today's individualistic world, where customers are looking for unique and personalized experiences. Here, it would also be beneficial to study how chain affiliation is viewed by the customers, and whether Western hotel brands are eventually perceived as superior in the emerging economy context. 


\section{Availability of data and material}

\section{The data is not publicly available due to contractual terms.}

Acknowledgements The authors want to thank Simo Leppänen for his contribution to an earlier version of the paper.

Author contributions PK had the main responsibility for the design of the survey instrument and organizing the data collection, and for writing the theoretical part. The hypotheses were formulated jointly with SL, who conducted the empirical analysis and wrote the sections reporting its results.

Funding The first author acknowledges the financial support for academic work from the Academy of Finland (Grant No. 64948).

Open Access This article is licensed under a Creative Commons Attribution 4.0 International License, which permits use, sharing, adaptation, distribution and reproduction in any medium or format, as long as you give appropriate credit to the original author(s) and the source, provide a link to the Creative Commons licence, and indicate if changes were made. The images or other third party material in this article are included in the article's Creative Commons licence, unless indicated otherwise in a credit line to the material. If material is not included in the article's Creative Commons licence and your intended use is not permitted by statutory regulation or exceeds the permitted use, you will need to obtain permission directly from the copyright holder. To view a copy of this licence, visit http://creativecommons.org/licen ses/by/4.0/.

\section{References}

Acquaah, M., \& Chi, T. (2007). A longitudinal analysis of the impact of firm resources and industry characteristics on firm-specific profitability. Journal of Management and Governance, 11(3), 179-213.

Agresti, A. (2010). Analysis of ordinal categorical data. (Vol. 656)Wiley.

Andrades, L., \& Dimanche, F. (2017). Destination competitiveness and tourism development in Russia: Issues and challenges. Tourism Management, 62, 360-376.

Barney, J. B. (1991). Firm resources and sustained competitive advantage. Journal of Management, 17(1), 99-121.

Barney, J. B., Ketchen, D. J., Jr., \& Wright, M. (2011). The future of resource-based theory: Revitalization or decline? Journal of Management, 37(5), 1299-1315.

Beaver, G., \& Prince, C. (2004). Management, strategy and policy in the UK small business sector: A critical review. Journal of Small Business and Enterprise Development, 11(1), 34-49.

Brookes, M., \& Roper, A. (2010). The impact of entry modes on the organizational design of international hotel chains. The Service Industries Journal, 30(9), 1499-1512.

Brouthers, K. D., Brouthers, L. E., \& Werner, S. (2008). Resource-based advantages in an international context. Journal of Management, 34(2), 189-217.

Brown, J. R., \& Dev, C. S. (1999). Looking beyond RevPAR: Productivity consequences of hotel strategies. Cornell Hotel and Restaurant Administration Quarterly, 40(2), 23-33.

Chung, W., \& Kalnins, A. (2001). Agglomeration effects and performance: A test of the Texas lodging industry. Strategic Management Journal, 22(10), 969-988.

Conner, K. R. (1991). A historical comparison of resource-based theory and five schools of thought within industrial organization economics: Do we have a new theory of the firm? Journal of Management, 17(1), 121-154.

Conway, J. M., \& Lance, C. E. (2010). What reviewers should expect from authors regarding common method bias in organizational research. Journal of Business and Psychology, 25(3), 325-334.

Dahlstrom, R., Haugland, S. A., Nygaard, A., \& Rokkan, A. I. (2009). Governance structures in the hotel industry. Journal of Business Research, 62(8), 841-847. 
Day, M., Lichtenstein, S., \& Samouel, P. (2015). Supply management capabilities, routine bundles and their impact on firm performance. International Journal of Production Economics, 164, 1-13.

Elvira, M. M., \& Cohen, L. E. (2001). Location matters: A cross-level analysis of the effects of organizational sex composition on turnover. Academy of Management Journal, 44(3), 591-605.

Fan, P., Liang, Q., Liu, H., \& Hou, M. (2013). The moderating role of context in managerial ties-firm performance link: A meta-analytic review of mainly Chinese-based studies. Asia Pacific Business Review, 19(4), 461-489.

Greene, W. H., \& Hensher, D. A. (2010). Modeling ordered choices: A primer. Cambridge University Press.

Guo, H., Xu, E., \& Jacobs, M. (2014). Managerial political ties and firm performance during institutional transitions: An analysis of mediating mechanisms. Journal of Business Research, 67(2), 116-127.

Holverson, S., \& Revaz, F. (2006). Perceptions of European independent hoteliers: Hard and soft branding choices. International Journal of Contemporary Hospitality Management, 18(5), 398-413.

Huddleston, P., Good, L. K., \& Stoel, L. (2001). Consumer ethnocentrism, product necessity and Polish consumers' perceptions of quality. International Journal of Retail and Distribution Management, 29(5), 236-246.

Ingram, P., \& Baum, J. A. C. (1997). Chain affiliation and the failure of Manhattan hotels, 1898-1980. Administrative Science Quarterly, 42(1), 68-102.

Ingram, P., \& Silverman, B. S. (2002). Introduction. In P. Ingram \& B. S. Silverman (Eds.), The new institutionalism in strategic management. (pp. 1-30). JAI Press.

Jaccard, J., Wan, C. K., \& Turrisi, R. (1990). The detection and interpretation of interaction effects between continuous variables in multiple regression. Multivariate Behavioral Research, 25(4), 467-478.

Jiang, F., Guo, H., Wei, Z., \& Wang, D. (2018). The fit between managerial ties and resource bundling capabilities: Implications for performance in manufacturing firms. IEEE Transactions on Engineering Management, 65(2), 216-226.

Karhunen, P. (2008). Managing international business operations in a changing institutional context: The case of the St. Petersburg hotel industry. Journal of International Management, 14(1), 28-45.

Karhunen, P., Kosonen, R., McCarthy, D., \& Puffer, S. (2018). The darker side of social networks in transforming economies: Corrupt exchange in Chinese guanxi and Russian blat/svyazi. Management and Organization Review, 14(2), 395-419.

Khanna, T., \& Palepu, K. (2000). The future of business groups in emerging markets: Long-run evidence from Chile. Academy of Management Journal, 43(3), 268-285.

Khanna, T., \& Palepu, K. (2010). Winning in emerging markets: A roadmap for strategy and execution. Harvard Business Press.

Ledyaeva, S., Karhunen, P., Kosonen, R., \& Whalley, J. (2015). Offshore FDI, capital round-tripping, and corruption: Empirical analysis of Russian regions. Economic Geography, 91(3), 305-341.

Li, H., \& Zhang, Y. (2007). The role of managers' political networking and functional experience in new venture performance: Evidence from China's transition economy. Strategic Management Journal, 28(8), 791-804.

Li, J. J., \& Zhou, K. Z. (2010). How foreign firms achieve competitive advantage in the Chinese emerging economy: Managerial ties and market orientation. Journal of Business Research, 63(8), 856-862.

Li, S., Park, S. H., \& Bao, R. S. (2014). How much can we trust the financial report? Earnings management in emerging economies. International Journal of Emerging Markets, 9(1), 33-53.

London, T., \& Hart, S. L. (2004). Reinventing strategies for emerging markets: Beyond the transnational model. Journal of International Business Studies, 35(5), 350-370.

Ma, H. (2000). Competitive advantage and firm performance. Competitiveness Review, 10(2), 15-32.

Manrai, L. A., Dana-Nicoleta, L., Manrai, A. K., \& Babb, H. W. (2001). A cross-cultural comparison of style in Eastern European emerging markets. International Marketing Review, 18(3), 270-285.

Marquis, C., \& Raynard, M. (2015). Institutional strategies in emerging markets. The Academy of Management Annals, 9(1), 291-335.

Mauri, A. J., \& Michaels, M. P. (1998). Firm and industry effects within strategic management: An empirical examination. Strategic Management Journal, 19(3), 211-219.

McGrath, R. G. (2001). Exploratory learning, innovative capacity, and managerial oversight. Academy of Management Journal, 44(1), 118-131.

Menicucci, E. (2018). The influence of firm characteristics on profitability: Evidence from Italian hospitality industry. International Journal of Contemporary Hospitality Management, 30(8), 2845-2868. 
Meyer, K. E., Estrin, S., Bhaumik, S. K., \& Peng, M. W. (2009). Institutions, resources, and entry strategies in emerging economies. Strategic Management Journal, 30(1), 61-80.

Mitsuhashi, H., \& Yamaga, H. (2006). Market and learning structures for gaining competitive advantage: An empirical study of two perspectives on multiunit-multimarket organizations. Asian Business and Management, 5(2), 225-247.

Newbert, S. L. (2008). Value, rareness, competitive advantage, and performance: A conceptual-level empirical investigation of the resource-based view of the firm. Strategic Management Journal, 29(7), 745-768.

O'Neill, J. W., \& Mattila, A. S. (2006). Strategic hotel development and positioning: The effect of revenue drivers on profitability. Cornell Hotel and Restaurant Administration Quarterly, 47(2), 146-154.

Peng, M. W. (2004). Identifying the Big Question in international business research. Journal of International Business Studies, 35(2), 99-108.

Peng, M. W., Lee, S. H., \& Wang, D. Y. L. (2005). What determines the scope of the firm over time? A focus on institutional relatedness. Academy of Management Review, 30(3), 622-633.

Peng, M. W., \& Luo, Y. (2000). Managerial ties and firm performance in a transition economy: The nature of a micro-macro link. Academy of Management Journal, 43(3), 486-501.

Pham, H. C., \& Richards, B. (2015). The Western brands in the minds of Vietnamese consumer. The Journal of Consumer Marketing, 32(5), 367-375.

Podsakoff, P. M., MacKenzie, S. B., Lee, J. Y., \& Podsakoff, N. P. (2003). Common method biases in behavioral research: A critical review of the literature and recommended remedies. Journal of Applied Psychology, 88(5), 879-903.

Porter, M. E. (1980). Competitive strategy. Free Press.

Porter, M. E. (1985). Competitive advantage: Creating and sustaining superior performance. Free Press.

Sainaghi, R. (2010). Hotel performance: State of the art. International Journal of Contemporary Hospitality Management, 22(7), 920-952.

Sharma, A., \& Christie, I. T. (2010). Performance assessment using value-chain analysis in Mozambique. International Journal of Contemporary Hospitality Management, 22(3), 282-299.

Sheresheva, M., Polyanskaya, E., \& Matveev, N. (2016). The Russian hospitality market: What is the basis for success in a challenging environment? Worldwide Hospitality and Tourism Themes, 8(3), 310-326.

Shleifer, A., \& Treisman, D. (2005). A normal country: Russia after communism. Journal of Economic Perspectives, 19(1), 151-174.

Tang, Q., Wang, L., \& Shen, H. (2019). How do SOEs and FIEs affect POEs' performance in emerging economies? Moderating effects of managerial ties. Asia Pacific Journal of Management. https://doi. org/10.1007/s10490-019-09684-y.

Transparency International (2021). Corruption Perceptions Index for Russia 2020. Retrieved Feb 03, 2021, from https://www.transparency.org/en/cpi/2020/index/rus.

Wang, G., Jiang, X., Yuan, C. H., \& Yi, Y. Q. (2013). Managerial ties and firm performance in an emerging economy: Tests of the mediating and moderating effects. Asia Pacific Journal of Management, 30(2), 537-559.

Wang, T., Zhang, T., \& Shou, Z. (2019). The double-edged sword effect of politicalties on performance in emerging markets: The mediation of innovation capability and legitimacy. Asia Pacific Journal of Management. https://doi.org/10.1007/s10490-019-09686-w.

Wilke, E. P., Costa, B. K., Freire, O. B. D. L., \& Ferreira, M. P. (2019). Interorganizational cooperation in tourist destination: Building performance in the hotel industry. Tourism Management, 72, 340-351.

World Bank (2012). Doing Business in Russia 2012: Subnational Doing Business. Retrieved Feb 03, 2021, from https://www.doingbusiness.org/en/reports/subnational-reports/russia.

World Bank (2021). Ease of Doing Business in Russian Federation 2020. Retrieved Feb 03, 2021, from https://www.doingbusiness.org/en/data/exploreeconomies/russia\#.

Wright, M., Filatotchev, I., Hoskisson, R. E., \& Peng, M. W. (2005). Strategy research in emerging economies: Challenging the conventional wisdom. Journal of Management Studies, 42(1), 1-33.

Publisher's Note Springer Nature remains neutral with regard to jurisdictional claims in published maps and institutional affiliations. 


\section{Authors and Affiliations}

\section{Päivi Karhunen ${ }^{1}\left[\right.$ (]) Svetlana Ledyaeva ${ }^{2}$ (]}

Svetlana Ledyaeva

svetlana.ledyaeva@aalto.fi

1 Center for Markets in Transition, Aalto University School of Business, PO Box 21230, 00076 Aalto, Finland

2 Department of Economics, Aalto University School of Business, PO Box 21240, 00076 Aalto, Finland 